ZBIGNIEW KAŹMIERCZYK

Uniwersytet Gdański

\title{
Filmowość języka poetyckiego Czesława Miłosza
}

\section{Pokolenie „wizualistyczne”- poezja a film}

Moment odzyskania niepodległości był jednym z czynników, który przyniósł literaturze polskiej swobodę przewartościowania tradycji, co sprzyjało inicjatywom nowatorskim. Ich różnorodność uniemożliwia ścisłe zdefiniowanie awangardy. Janusz Sławiński zauważył, że jest to „nazwa-worek” i „nie pozwala na przeprowadzenie nawet najbardziej prymitywnych ograniczeń” (Sławiński 1965: 8). Wskazanie pewnego warunku awangardyzmu okazało się jednak możliwe. Edward Balcerzan stwierdził sentencjonalnie, że ogólnie duchem awangardy jest „Z żywymi naprzód iść, po życie sięgać nowe” (zob. Balcerzan 1982). Według Marka Zaleskiego jednym z przejawów poczucia nowości życia poetów drugiej awangardy było przekonanie o potrzebie nowego obrazowania świata. Jerzy Zagórski jego wytyczną znalazł w porównaniu sztuk słowa i obrazu: „Elementy wzrokowe najbardziej sprzyjają powstaniu nowego wiersza. Pokolenie obecne, a właściwie przedstawiciele jego najbardziej zaawansowani - jest wybitnie wizualistyczne" (cyt. za: Zaleski 1984: 226). Zdanie to świadczy nie tylko o poczuciu nowości sposobów komunikowania się z publicznością, ale również o zrozumieniu przez żagarystów, że następuje „kres wielowiekowej hegemonii słowa pisanego i drukowanego" (Bauchrowicz-Kłodzińska 2018: 106), że mijają epoki ich monopolu jako „wzorców dla innych systemów znakowych” (Hopfinger 1974: 130), że wyzwaniem czasu jest otwarcie poetyki na sytuację nadawcy 
i odbiorcy stworzoną przez telegraf, telefon, radio, kino, prasę. Że pora na zawarcie „związku między literaturą odnowioną kinem i kinem uszlachetnionym poezją" (Otto 2007: 34). Świadomość nowej sytuacji komunikacyjnej kierowała ich uwagę na teorię i praktykę poetycką awangardy krakowskiej². Uważała ona kino za najbardziej efektowny przykład osiągnięć kultury materialnej, za „przejaw potęgującej się roli środków masowej komunikacji i technik masowej reprodukcji w życiu codziennym mieszkańców wielkich miast" (Zaleski 1984: 26). Tadeusz Peiper widział w rozwoju mediów gwarancję pożądanej globalizacji. Napisał w manifeście Nowe usta: „Po odkryciu radiokinematografii będziemy mogli niemal równocześnie z mieszkańcami Paryża czy New Yorku przeżywać wypadki ich miast. Świat stanie się tak mały, że wkrótce nosić go będziemy w kieszonce od kamizelki" (cyt. za: Zaleski 1984: 26).

Zaleski zauważył związek między zainteresowaniami kinem a poetyką awangardy krakowskiej oraz żagarystów: „Nowatorów fascynowało kino: montaż filmowy podsuwał pomysły nowych rozwiązań poetyckich” (Zaleski 1984: 26). Wpływem filmowego montażu wyjaśnił fakt, iż teksty wilnian,

będąc zestawieniem niejednorodnych sytuacji lirycznych i zdarzeń realistycznych, aluzji do scen mitologicznych i historycznych, słowem fragmentów realności nie przystających do siebie często tak pod względem usytuowania w czasie, jak i w przestrzeni, i nie wchodzących ze sobą w dające się logicznie umotywować związki przyczynowo-skutkowe - były często jednocześnie tekstami rygorystycznie domkniętymi i uporządkowanymi zważywszy na ich tradycyjny kontur wersyfikacyjny (Zaleski 1984: 229).

1 Stefan Jędrychowski ostrzegał przed ryzykiem znalezienia się literatury w komunikacyjnej ariergardzie: „Radio, kino, telefon, auto, aeroplan - to czynniki, które nadają piętno współczesności. Zaryły się one tak głęboko w grunt, wywołały tak daleko idące wyrwy w psychice, że literatura musi pospieszyć, aby za nimi nadążyć" (Jędrychowski 1931: I).

2 Ich uwagę przyciągali także futuryści. Odnotujmy, że futuryzm jako pierwszy kierunek awangardowy piórem Aleksandra Wata w Bezrobotnym Lucyferze złożył dwuznaczny hołd kinematografowi - maszynie znanej wtedy światu od ćwierćwiecza. Lucyfer w świecie dostatku zła znajdzie w końcu pracę, będzie „,anarchistą tańczącym z maszyną” (zob. Brodzka 1975: 569-570). Wat, dostrzegając diabelską stronę magii kina, doceniał jego zdolność do kreowania wyobraźni i emocji mas i brał pod uwagę, że może to być niekiedy panowanie diabelskie (zob. Wat 1993: 102). Czy nie jest to m.in. wpływ „ekranu demonicznego" opisanego przez Lottę Eisner? Autorka dowodzi, że oko kamery posługuje się montażem, „ruchomymi wizjami, by odmalować uczucia” (Eisner 2011: 147). 
W ten sposób technika montażu przekroczyła poziom jukstapozycji zdań i zawładnęła opisem oraz kompozycją tekstu:

Kalejdoskopiczna kompozycja kroniki filmowej była atrakcyjna jako model poetyckiego toku reportażowego w wierszach społecznie zaangażowanych. I później przestrzenna głębia kadru filmowego umożliwiająca równoczesność ujęć różnych zdarzeń pozostawała nadal frapująca dla poetów zainteresowanych nielinearną, symultaniczną perspektywą (Zaleski 1984: 220).

\section{Technika montażu}

Czy stwierdzenie podobieństwa montażu filmowego i obrazowania żagarystów pozwala mówić o filmowości języka poetyckiego Miłosza? W jego biografii artystycznej okres twórczości uwieńczony tomikiem Trzy zimy (1936) określany jest jako faza „zaklinania losu” (Burek 2001: 17), okres, kiedy poeta występuje w roli ucznia i „ukazuje świat sub specie aeternitatis z odcieniem sub specie apocalipsis" (Kwiatkowski 1985: 61). Już Kazimierz Wyka zauważył w poezji żagarysty efekty optyczne właściwe soczewce. Stwierdził, że jest to „soczewka gruba i najbardziej indywidualnie polaryzująca rzeczywistość” (Wyka 1985: 18). Badacz ten mówił o przedwojennym okresie wędrówki podmiotu poezji Miłosza po „ogrodach lunatycznych”, kiedy patrzył na świat przez „soczewkę egotyczną” (Wyka 1985: 16).

Stanisław Barańczak w artykule Język poetycki Czesława Miłosza nawiązał do tezy Wyki „o «filmie jako zasadzie znaczeń» tej poezji” tworzonych „techniką płynnego łączenia obrazów, montażowych cięć umożliwiających szybką zmianę scenerii" (Barańczak 1985: 427). Tezą artykułu, który jest gotowym, lecz niezrealizowanym projektem książki o poezji Miłosza, uczynił konstatację filmowości jej języka. Porównując film i wiersz, wyjaśnił synekdochicznością stylu noblisty adekwatność języka x Muzy do analizy jego języka: zbliżenia, detalu, planu, ujęcia, sekwencji, perspektywy, panoramy, transfokatora, a przede wszystkim montażu: „Można by powiedzieć, że technika Miłosza w tym wczesnym okresie (i doraźnie także później, aż po ostatnie tomy) polega na synekdochicznym użyciu języka” (Barańczak 1985: 426)3. „Miłosz jest poetą synekdochy” (Barańczak

3 „Tym, co szczególnie Miłosza w tej dziedzinie wyróżnia - podkreślił Barańczak - jest daleko posunięta rezygnacja $\mathrm{z}$ tropów zbliżonych do bieguna metaforycznego - przede wszystkim z symbolu i metafory w węższym sensie - oraz symetryczne upodobanie do tropów metonimicznych, przede wszystkim do synekdochy. Miłosz to poeta synekdochy: 
1985: 426), to znaczy tworzy szeregi partes pro toto, dzięki którym „schodzi jak najniżej po szczeblach semantycznej drabiny abstrakcji” (Barańczak 1985: 425) na spotkanie rzeczy i nazwy, jak w wierszu Przypomnienie:

\author{
I usta złączone \\ Nad światłem liczników \\ Jechały asfaltem \\ Pod skrzydłem pomników (Miłosz 2002: 58)
}

skokowo dodaje części całości, czyli parę kochanków, samochód, drogę, miasto, a skokowość ta jest odpowiednikiem montażu i pełni jego funkcję: znaczącego łączenia. Według Barańczaka, czym jest łączenie synekdoch (jukstapozycja), tym jest montaż ujęć filmowych, czym ich szeregi, tym sekwencja. Dla podkreślenia filmowości języka poetyckiego Miłosza traktuje on szereg i sekwencję synekdoch synonimicznie ${ }^{4}$. Uruchomienie pojęć języka filmu stosowanych w analizie filmoznawczej przydatne jest Barańczakowi do potwierdzenia i uwyraźnienia tezy o synekdochiczności języka poetyckiego Miłosza. Poprzez porównanie poezji i filmu wykazuje on, że synekdochiczność jest poetycką techniką montażu, i mówi o „filmowo-synekdochicznej technice” noblisty (Barańczak 1985: 429). Nie znaczy to, że Miłosz posługuje się językiem filmu, bo literatura nie ma takiej zdolności ${ }^{5}$. Poprzez porównanie z filmem i zastosowanie pojęć z jego języka możliwe jest jednak wydobycie specyfiki twórczości poetyckiej autora Trzech zim, ukazanie jego techniki synekdochiczno-filmowej. Barańczak wyróżnia jej podstawowe warianty: od szczegółu do ogółu, od szczegółu do ogółu i z powrotem, od ogółu do szczegółu, od zbliżenia do ujęcia z lotu ptaka.

Za istotne osiągnięcie techniki poetyckiej Miłosza uznał on zdolność ujmowania dali i bliskości w jednym ujęciu. Ta zdolność zastąpienia montażu zmianą

krytyka chyba nigdy nie podkreśliła tego dostatecznie, a przecież jest to cecha i wyraźna, i nasilająca się w jego twórczości z biegiem lat" (Barańczak 1985: 425-426).

4 Za przykład służy Barańczakowi wiersz Równina: „Łatwo sobie wyobrazić filmową sekwencję ujęć, która ukazywałaby przygnębiający nastrój mazowieckiej równiny w sposób dokładnie taki, jak to uczynił Miłosz: przez następstwo planów od ogólnej panoramy (kartofliska), poprzez plan pełny (pólko koniczyny), aż do zbliżenia i detalu (końskie pyski, komary)" (Barańczak 1985: 427).

5 W analizach porównawczych literatury i filmu niekiedy filmowość i literackość opatrzone są cudzysłowem jako znakiem trudności wyraźnego zdefiniowania pojęć i jeszcze trudniejszego ustalania podobieństw i różnic między sztuką słowa a x Muzą. Rafał Koschany za miejsce wspólne „literackości” i „filmowości” uznał narrację, fikcję oddającą przebieg życia ludzkiego w czasie - egzystencję oraz wyobraźnię (zob. Koschany 2007: 13). 
przestrzeni w jednym ujęciu porównana została do właściwości transfokatora, czyli szczególnego rodzaju obiektywu zmienno-ogniskowego.

\section{Synekdocha a wielogłosowość}

Synekdochiczo-filmowa technika została przez Barańczaka potraktowana jako algorytm strukturalny poetyckich światów Miłosza. Według badacza jej pochodną jest wielogłosowość wierszy noblisty. Poetyka skorelowana z etyką, filozofią i teologią służy nie tylko zapisowi „szczegółów, «akcydensów życia», które są niedoskonałymi reprezentantami całości, [...] ale również mnożeniu świadectw o niej. Świadectw przynależnych różnym punktom widzenia, różnym miarom wartości, różnym głosom” (Barańczak 1985: 231-232). Motywuje lirykę roli i lirykę maski. W okresie przynależnym, według Ryszarda Nycza, „poetyce parabolicznej autobiografii” w wyniku działania algorytmu strukturalnego poetyckiego języka Miłosza „ "Cudzy głos» i «cudze słowo» są istotnie metodami zdobycia się na autoironiczny dystans względem własnego ego" (Barańczak 1985: 434), który pozwala - mówi z kolei Nycz - uczynić z autobiografii „pouczające exemplum ludzkiego losu" (Nycz 2011: 21) ${ }^{6}$.

\section{4. „Niby-kamera”}

Aleksander Fiut, opisując język żagarysty, w miejsce soczewki wprowadził pojęcie obiektywu. Stwierdził, że już w pierwszych wierszach obiektyw ten służy ekspresji poetyckiej, „uwzględnia bowiem rozmaite nastawienia patrzącego” (Fiut 1993: 16). Obiektyw ten zmienia położenie i ukazuje świat raz w zbliżeniu, raz w oddaleniu, przy czym rozmaitym perspektywom towarzyszy różnorodna treść emocjonalna: „Trzymając się metaforyki filmowej można by powiedzieć, że posługując się kamerą poeta zmienia w niej filtry" (Fiut 1993: 16). Według Fiuta zmienna perspektywa skorelowana jest w poezji żagarysty z emocjami:

Ostro dymiły równiny wklęsłe jak sine misy. Na ich

krawędziach ognie, salwy, reflektory. [...]

6 Ustalenia Nycza są zbieżne z periodyzacją Barańczaka, gdy mówi Nycz o najwcześniejszej „poetyce wizyjnej potoczności”, charakteryzującej się m.in. „prymatem metonimii nad metaforą", o „poetyce publicznego dyskursu” „,ukazującej «faktyczne» oblicze rzeczywistości”, a także o „poetyce parabolicznej autobiografii - ponawiania tożsamości piszącego i prawdy o (nie tylko jego) przeszłości” i „poetyce wskazywania pozaludzkiego” (Nycz 2011: 18, 20-21, 22, 27). 
zaryglowane milczały,

Na przedmieściach, gdzie domy

zatrzymał się tank. Każdy hełm załogi na śmierdzącej masie

krwi i potu pływa.

Jeżeli nie naprawią motoru w ciągu godziny -

Więc klęczą, ręce drgają od gorączki. W piach cieknie ruda oliwa.

(Miłosz 2001: 18, Pora)

W tym odczytaniu wiersz jest serią „przejść niby-kamery od planu ogólnego i uniwersalnego ( «ostro dymiły kominy» to jakby obraz z apokalipsy) do zbliżenia, które zatrzymuje poetycki obiektyw na jednym, wyodrębnionym szczególe (spływająca oliwa)" (Fiut 1993: 16).

\section{5. „Widząc świat metonimicznie, poeta rozumie go i odczuwa metaforycznie"?}

Koncepcja języka poetyckiego Barańczaka stała się istotnym punktem odniesienia dla Fiuta. Autor Momentu wiecznego również dostrzegł w poezji Miłosza technikę metonimiczno-filmową - „dodawania do siebie obserwowanych przedmiotów lub scenek” oraz „oscylacji pomiędzy tym co bliskie, a tym co odległe” ruchliwej „niby-kamery” poety (Fiut 1993: 16-17). Jednak główne założenia swej pracy o poezji Miłosza sprecyzował on w polemice z koncepcją poezji oczyszczającej się z metafor i symboli dzięki prymatowi synekdochy wspomaganej małymi zaledwie metaforami. Podkreślił niewydajność obu technik w budowie „spójnego obrazu rzeczywistości” (Fiut 1993: 30), czyli technik dodawania w montażu i ruchu w obrębie jednego ujęcia, gdyż bez instancji nadrzędnej niemożliwa jest hierarchia bytów i dlatego rzeczywistość jako całość „umyka metonimiom i synekdochom” (Fiut 1993: 21). Bez tej instancji świat pozostaje "niekompletną sumą obserwowanych przedmiotów” (Fiut 1993: 21). Badacz stwierdził ewolucję poezji Miłosza w stronę metaforyzacji: „Widząc świat metonimicznie, poeta rozumie go i odczuwa metaforycznie” (Fiut 1993: 23). W nawiązaniu do odczytania Barańczaka interpretuje wiersz Równina „nie jako przedstawienie zbioru przypadkowych przedmiotów oglądanych na przemian z bliska i z daleka” (Fiut 1993: 18), ale jako wielką przenośnię „zagłady świata” Warto może zauważyć, że polemika z Barańczakiem jest tu bezprzedmiotowa.

7 W opozycji do Barańczaka apokaliptyczną interpretację Przedmieścia zaprezentowali Aleksandra Okopień-Sławińska (2000: 212-229) oraz Michał Głowiński (2000: 197-211). 
Dostrzeżenie dominacji techniki synekdochiczno-filmowej z pomocniczym zaledwie udziałem małych metafor w obrazowaniu świata przez Miłosza nie wyklucza w analizie Barańczaka apokaliptycznej, eschatologicznej wymowy wiersza. Obserwacja badacza, iż wiersz Piosenka o końcu świata „stanowi właściwie serię synekdoch, wspólnie składających się na obraz tytułowego «świata»" (Barańczak 1985: 429), nie oznacza, że nie dostrzega on w nim gnostyckiego mitu apokatastasis. Respekt części dla całości rzeczy pozwala się metonimii obyć bez metaforycznej manipulacji przedmiotem. Koncepcja obrazowania przez Miłosza pozwala Barańczakowi odczytywać obrazek rodzajowy także metahistorycznie. Synekdochiczno-filmowe obrazowanie nie niweczy w tej koncepcji metahistorycznego transcendowania znaczeń. Synekdocha, odsyłając do całości, zdolna jest ustanowić hierarchię spraw tego świata bez odbierania rzeczom nazw. W referacie Miłosz: 'Sześć wykładów wierszem'. Preliminaria interpretacyjne (1991) Barańczak przedstawił wszechstronną analizę wiersza jako exemplum języka i techniki poetyckiej Miłosza. Dowodzi w niej, że najważniejszym motywem wypowiedzi lirycznej Miłosza jest „opowiedzieć wszystko”:

Metodą nagłych jukstapozycji rzeczy i istnień zajmujących skrajnie odległe miejsca w przestrzeni, czasie i potocznie zakładanej hierarchii ważności zjawisk, w obrębie zaledwie jedenastu wersów Miłosz ustanawia czterowymiarowy (bo zanurzony też w wymiarze czasu, historycznego i biologicznego trwania i mijania) świat-replikę. Świat, w którego granicach (jesteśmy niemal gotowi w to uwierzyć na zasadzie pozaracjonalnej suspension of disbelief) może istotnie da się zmieścić „Wszystko”, całość ludzkiego doświadczenia autora i jego epoki, skoro pomieściło się już tyle: od skrzydeł ważki do odrzutowca, od pogody letniego spaceru po „ból nieobjętej liczby, a każdy inny”, od „cementu na krematoria” po „tranzystor” i „video”, od zagłady i zniszczenia aż po „ludzi na Księżycu” (Barańczak 200o: 246-262).

Jest to możliwe dzięki „zogniskowaniu spojrzenia” na „ekranie poematu”, dzięki „obserwującej i filmującej wszystko kamerze” (Barańczak 200o: 259). Niejako w polemicznym ferworze z Fiutem Barańczak powtórzył - a ze względu na wagę tych słów przytoczymy całą wypowiedź:

Jak to już dostrzegli liczni krytycy, Miłosz był zawsze poetą metonimii, czy zwłaszcza tej odmiany metonimii, jaką jest synekdocha albo pars pro toto. Dopiero jednak Sześć wykładów wierszem pozwala nam zdać sobie sprawę z ogromu znaczenia, jakiego ten stylistyczny wybór 
nabiera w obrębie filozofii Miłosza - tak ontologii, jak gnoseologii i wreszcie etyki. Wystarczy przeczytać paręnaście pierwszych wersów wykładu III - które przywodzą na myśl techniki filmowe wykorzystujące ruchomą kamerę, teleobiektyw o zmiennej ogniskowej i stół montażowy po to, aby panoramiczny obraz anonimowego, odczłowieczonego tłumu rozbić na pojedyncze sylwetki i twarze - a zdamy sobie sprawę, co synekdochiczne widzenie Miłosza reprezentuje i na co jest mu potrzebne. Reprezentuje mianowicie jego przekonanie, że jedynym naprawdę istotnym zadaniem poezji jest stawianie oporu triumfalnemu rozrostowi antyludzkiego zła, manifestującego się w znamiennym dla nowoczesnej historii „uogólnieniu”. Potrzebne jest po to, aby wiersz mógł dokonać swego niezbędnego zstąpienia na poziom indywidualnego doświadczenia ludzkiego; zstąpienia, które - choć to może zabrzmi jak bluźnierstwo - stanowi dla poety dostępną tylko jemu i jedyną naprawdę mu dostępną formę imitatio Christi (Barańczak 2000: 261).

Jak widzimy, po upływie dekady Barańczak pogłębił argumentację dotyczącą filmowości języka poetyckiego Miłosza i uzasadnił swą koncepcję religijnie. Potwierdził zdolność techniki synekdochiczno-filmowej do „opowiedzenia wszystkiego". Rok później opublikował tekst wcześniejszy Summa Czesława Miłosza, który ukazuje krystalizację jego koncepcji filmowości języka poetyckiego Miłosza. Zwrócił uwagę na ujawnienie przez Miłosza w Ziemi Ulro temperamentu manichejskiego, ale inaczej rozumiał swe pokrewieństwo: „Mając się za manichejczyka, Miłosz uważa za bliskich sobie wszystkich tych, którzy konsekwentnie rozróżniają dobro i zło, choćby byli ateistami" (Barańczak 2002: 262-263). Podkreślając związek teologii, filozofii i etyki Miłosza z poetyką, skorelował jego technikę poetycką z pokorą wobec rzeczy, wobec konkretu; istnienia poszczególnego. Wielki temat natury jako dzieła demiurga i gnostycko-manichejskiej kontestacji świata oraz jej związku z poetyką Miłosza pozostał poza uwagą Barańczaka.

\section{Poetyka a egzystencja}

Do zagadnienia tego zbliżył się dekadę później Nycz. Omawiając „poetykę wskazywania pozaludzkiego”, dowodzi on, że Miłosz wykraczał poza „humanizację pozaludzkiego", gdyż uznał, że antropomorficzna „wyprawa w pozaludzkie jest najzupełniej pozorna" (Nycz 2011: 27). Pozorne są więc także epifaniczne formy poetyckie, ponieważ przesuwają granice świata ludzkich projekcji, ale ich nie przekraczają. Zdaniem Nycza ich iluzoryczność stwierdzona została 
w wierszu TO jako „ćwiczenia wysokiego stylu”. Przekroczenie granic pozaludzkiego jest według badacza ich otwarciem na chaos i nicość, jest odrzuceniem „epifanicznego usensowniania doświadczanego świata” (Nycz 2011: 28). W ujęciu tym Miłosz jest otwarty na egzystencjalizm, na „nieprzenikalną obcość pozaludzkiego świata” (Nycz 2011: 29). Nycz nie rozważa jednak gnostycko-manichejskiego charakteru doświadczeń egzystencji w poezji noblisty. Uważa za ostateczne słowa Miłosza: „A pod spodem było To, czego nie podejmuję się nazwać” (Miłosz 2009: 83, TO).

A przecież wiersz ten element „TO” nazywa. „TO” jest odsłaniane w serii ciemnych teofanii gnostycko-manichejskich. Gnostycko-manichejskie doświadczanie egzystencji (zob. Kaźmierczyk 2011) zapisane jest już we wczesnych tomikach żagarysty, zwłaszcza w Trzech zimach, i skorelowane jest z jego poetyką.

\section{Technika rewolucyjna}

Miłosz przeciwny temu, „aby sam autor sporządzał filozoficzny komentarz do swoich wierszy" (Miłosz 1990: 132), wprost nie odnosi się do zagadnień techniki synekdochiczno-filmowej, ale wskazuje ją jako sobie bliską. Mówi o swej wczesnej fascynacji Dionizjami Jarosława Iwaszkiewicza oraz opartym na montażu jako głównym środku wyrazu - filmem Pudowkina Burza nad Azją, który stał się kanwą jego metonimicznego wiersza Twarz mężczyzny ${ }^{8}$. Zdradzając swą fascynację literacką siedemnastolatka, wspomina odkrycie techniki filmowego montażu zwanej szwenkiem: „Otóż raptem odkryłem u Iwaszkiewicza gwałtowne przeskoki, załamania metrum: wyzwolenie” (Miłosz 1990: 133).

\section{Od stateczności do płynności obrazowania}

Jak widzieliśmy w wierszu Pora, technika montażu filmowego jest modelem obrazowania poetyckiego Miłosza. Jest to jednak montaż ujęć obiektywu pozbawionego zmiennej ogniskowej - transfokatora. Ujęcia składają się w se-

8 W liście do Jarosława Iwaszkiewicza Miłosz ujawnia rewolucyjne upodobanie do wieloplanowości, zbliżenia i montażu: „Marzę o obrazach, gdzie tragizm jest zepchnięty na dno, o maskach zupełnie spokojnych, zastygłych klasycznych, mięśnie twarzy mają napięte [...], o kompozycjach, w których wszystko jest gładkie, senne - aż pęka w finale i wali, rwie wszystko na strzępy - jak Burza nad Azją Pudowkina” (Miłosz, Iwaszkiewicz 2011: 18). Według Siegfrieda Kracauera montaż u Pudowkina „jest podobny do wstrząsów obliczonych na przekształcenie opowieści w dialektyczny proces, który kończy się triumfem proletariatu" (Kracauer: 2009: 163). 
kwencję. Następują po sobie i wiążą się w zmiennej perspektywie. Obiektyw kamery nastawiony jest na plan ogólny, zostaje wyłączony, przedstawia kolejną perspektywę, aż znajdzie się przy czołgu. Wtedy jest kolejny raz wyłączony, po czym - w kolejnym ujęciu - widać wsiąkającą plamę na piasku. Ujęcia dodawane są skokowo. W wielu wierszach Poematu o czasie zastygłym i powstałych w tym okresie wyobraźnia poetycka Miłosza cechuje się podobną statecznością. Obrazuje on świat w obiektywie, który musi zmieniać położenie, aby objąć raz plan daleki, a raz bliski, ale jeszcze nie posługuje się szwenkiem. Ruch odbywający się w danym kadrze pozwala jednak mówić nie o fotografii, ale o ujęciach filmowych. Rzeczywistość wyłania się na zasadzie dodawania jej fragmentów. Można jednak zauważyć, że to jest obiektyw bezogniskowy. Jak wiadomo z optyki, ogniskowa to kąt załamania fal. Dzięki zmianie tego kąta obiektyw nie musi zmieniać położenia, aby pokazać bliskie i dalekie, a co ważniejsze, ujmuje rzeczywistość w jednej fazie czasu.

Według Jerzego Kwiatkowskiego w Poemacie o czasie zastygłym i w wielu wierszach z Trzech zim „patosowi rytmu odpowiada patos wyobraźni. Miłosz monumentalizuje obrazy, ukazując je w możliwie szerokich - czasowo, przestrzennie i pojęciowo perspektywach" (Kwiatkowski 1985: 61). Biorąc pod uwage gnostycki typ kontestacji świata reprezentowany przez podmiot poezji Miłosza, można stwierdzić, że jego oku właściwa jest perspektywa eonu, czyli czasoprzestrzeni rozległej - odwiecznej i globowej, którą usilnie równoważy zbliżeniem. Przez brak techniki panoramicznego odjazdu i najazdu widoczny jest w tej poezji niedowład przejść od oglądu ogólnego do poszczególnego i vice versa. Energia nie pokory, ale kontestacji świata pozbawia go przedmiotów i zjawisk mikrokosmicznych oddawanych z pietyzmem w ruchu. Jego obiektyw ustawiony w kosmiczną dal zna montaż, ale w Poemacie o czasie zastygłym $\mathrm{z}$ trudem zdobywa się na ruch od planu ogólnego do zbliżenia w jednym ujęciu.

W Poemacie o czasie zastygłym i w Trzech zimach poetycki montaż jest pochodną lokowania się podmiotu w perspektywie globalnej lub poza światem. Ukazywanie czasoprzestrzeni jako eonu służy ekspresji gnostyckiego dualizmu, czyli rozłamu pomiędzy niechcianym światem i upragnionym nadświatem. Optyka nieskończonej dali ustatecznia, a nawet unieruchamia ogniskową obiektywu żagarysty. Nadmiar czasu i przestrzeni pogardzanych jako demoniczny eon kładzie się ciężarem znieruchomienia zmiennej optycznej.

Tak statecznie w poezji tej obrazowany jest pejzaż monumentalnej Północy, zwłaszcza w Poemacie o czasie zastygłym. W wierszu Ląd (wizje) litewskie drogi pną się zawsze na wzgórza i nikną poza horyzontem albo przepadają „zgięte jak ramiona mątew" (Miłosz 2001: 24, Ojczyzna). Krajobraz rozpościera się od wschodu słońca do zachodu. Jego rozległość potęguje motyw wiatru wiejącego 
w niezmierną dal i dookolny ruch słońca. Ubezkresowienie ziemi jest w tych wierszach mimowolne, gdyż jest ekspresją wewnętrznego doświadczania egzystencji jako wrogiego bezmiaru. W wierszu Bieg podmiot niczym mityczny przybysz $\mathrm{z}$ innej planety oznajmia w następujących po sobie obrazach od szczegółu (synekdocha bosej nogi) do ogółu:

Zszedłem bosą nogą na ziemię zakrytą wielkimi śniegami od jednej granicy widnokręgu do drugiej (Miłosz 2001: 57, Bieg).

Wyjątkowa pozycja wiatru wśród elementarnych żywiołów: ognia, ziemi i wody wynika z obrazowania nieskończonej otwartości przestrzeni. Podmiot jest wobec niej samotnikiem przeżywającym dramat bezkresności swej wyobraźni. Lot $\mathrm{w}$ nieskończoną dal na wietrze jest emblematem dotkliwej tęsknoty do nieograniczoności.

Pomiędzy demoniczną przestrzenią i wiatrem a personą wiersza Podróż wytworzona jest analogia. Złowroga przestrzeń industrialna jest gościńcem odbitym w osobliwym lustrze świadomości poety. W poezji tej mimo elementów poetyki futuryzmu - samolotów jako „trójśmigłych statków”, motorów, wiatraków, drutów telefonicznych - daleko jesteśmy od cywilizacyjnego optymizmu. Optymizm nieomal integralny jest wyróżnikiem awangardowości. Jak postulat nowej poezji brzmi wezwanie w dodanych obrazach: „Opowiadajmy niebieskie baseny, oszklone dachy nad nimi / i słońce” (Miłosz 2001: 121, Dytyramb).

Wiersz Dysk jest zapisem rozdźwięku pomiędzy deklarowanym optymizmem cywilizacyjnym a faktycznym stanem psychicznym. Podmiot, zaciekawiony, patrzy na rzekę zanieczyszczoną żółtą substancją, na pyły „mosiężnych, zastygłych obłoków” (Miłosz 2001: 16). Podobnie jest z nowoczesnymi środkami lokomocji. W górze „mruczą w powietrzu nowe R. W.D.” (Miłosz 2001: 22, Ląd (wizje)), innym razem samolot „leci pod kątem $45^{\circ}$ do poziomu miasta pochylony” (Miłosz 2001: 16, Dysk), a w innej stronie samoloty pasażerskie przelatują „na wysokości 5000 metrów” (Miłosz 2001: 17, Luli). Poniżej „Lokomotywy bez ustanku wyprzedzają dym na leśnych torach” (Miłosz 2001: 20, Ląd (wizje)).

Topika awangardowa Miłosza wyraża pesymizm cywilizacyjny, bo jest on zbuntowany metafizycznie, a zachwycające samoloty i pociągi budzą ostatecznie w nim grozę jako zwiastuny wojny. Podmiot tej poezji zdaje sobie sprawę z buntowniczego charakteru swego stanu emocjonalnego. Chciałby afirmować przemysłową rzeczywistość jak poeta awangardowy, ale cierpi na skrajne poczucie marności wszystkiego, co żyje i jest wzniesione ludzką ręką. Miłości do ludzi, świata i samego siebie zadekretować nie może. Zdolność do afirmacji życia, jak miłość, należy do sfery emocji, a emocje podmiotu są w sprzeczności z jego 
wolą. Chodzi zaś o emocje wywoływane swoistym doświadczaniem egzystencji. Podmiot ma skłonność do inwersji teologicznej. Demonizuje ziemię i „wód obszary". Obrazuje je jako domenę zła. Człowieka animalizuje. Przedstawia go jako bezwolne narzędzie pierwotnych popędów. Traci wiarę w ziemię jako dzieło kreacji Bożej. Jego pragnienie sensu istnienia naraża go na rozpacz. Rozpacz egzystencjalna persony wielu wierszy jest skorelowana z niezdolnością do afirmacji widzialnego świata. Rozpacz trawi zdolność persony do miłości. Zarazem sensualna wrażliwość powoduje popadanie podmiotu w osobliwe ekstazy na łonie natury. Pełen awersji wobec jej praw, zachwyca się pięknem. Jego wyobraźnię nawiedzają obrazy śmierci organizmów żywych. Wrażenie piękna i ostra świadomość koszmaru egzystencjalnego i historycznego stanowią osobliwą jedność. Dlatego w poezji tej pojawiają się zwroty wyrażające gnostycką ambiwalencję. Rozległa ziemia jawi się jako „szeroka, piękna ojczysta i krwawa” (Miłosz 2001: 49, 2 strofy). Jest to ziemia darwinowskich praw obowiązujących nie tylko w naturze, ale i w dziejach. Utrata tradycyjnych wyobrażeń religijnych, czyli wyzwolona skłonność do widzenia ziemskiego koszmaru, dobrze wyraziły się w pejzażu Północy.

Technika montażu służy młodemu Miłoszowi do ekspresji nie afirmacji, lecz kontestacji materialnego świata. Nie przypadkiem obrazowanie w Poemacie o czasie zastygtym i w Trzech zimach kojarzy się z ekspresjonizmem, gdyż „ujęcia z lotu ptaka, z kosmicznego oddalenia - to ulubione chwyty ekspresjonistów" (Fiut 1993: 16). Przykładem umieszczenia obiektywu wysoko nad linią horyzontu jest wiersz W tym właśnie kraju. Motywacją wypowiedzi „my” lirycznego jest zabranie czytelnika w lot: „I płyniemy po ziemi jak niebem gwiazd rzeki” (Miłosz 2001: 53). W sposób charakterystyczny obrazy są w locie dodawane do siebie na zasadzie filmowego montażu. Daleko w tle widoczna jest puszcza, bliżej we wsi widzimy strzechy chałup białoruskich. Na zasadzie przeskoków przestrzennych trafiamy wreszcie do wnętrza chaty.

Technikę zmiennej ogniskowej poeta rozwija stopniowo w gnostycko-manichejskich Trzech zimach, a swobodę panowania nad nią osiąga dopiero wraz ze zdolnością afirmacji rzeczywistości ciała i materii w tomiku Świat. Poema naiwne. Oto jeden z niezwykłych przykładów:

Ziemia to ziarnko - naprawdę nic więcej,

A inne ziarnka - planety i gwiazdy.

A choć ich będzie chyba sto tysięcy,

Domek z ogrodem może stać na każdej.

(Miłosz 2001: 200, Przypowieść o maku) 
Zawrotne zbliżenie w jednym ujęciu kosmicznej dali osiągnięte jest przez najazd (travelling) na domek z ogrodem. Podobny przykład zmiennej ogniskowej dają gnostycko-manichejskie Ptaki:

Schodzi uczeń marzenia na północne kraje, Ogniem błyszczy jak Cyrus, morduje pokrzywy.

(Miłosz 2001: 63, Ptaki)

Ukazanie bliskiego i dalekiego w jednej fazie czasoprzestrzeni to uchwycenie przez ruchomą ogniskową rzeczywistości w ruchu. Odpowiednik filmowego szwenku. W tym wierszu to, co poszczególne, wchodzi w związek ciągłości z ogólnym. Uczeń marzenia tworzy ze światem napięcie jednostkowego z tym, co bezmierne. Ruch łączy oba plany, nadając im głębię.

O tym, jak ważne były dla Miłosza kwestie ogniskowej, świadczy mowa noblowska. Wrócił w niej do antynomii, która organizowała jego wyobraźnię poetycką:

Ziemia, na którą patrzył poeta w swym locie, wzywa krzykiem zaiste z otchłani i nie pozwala się oglądać z wysoka. Powstaje niepokonalna sprzeczność, realna, nie dająca spokoju w dzień i w nocy, jakkolwiek ją nazwiemy, sprzecznością pomiędzy bytem a działaniem, czy sprzecznością pomiędzy sztuką i solidarnością z ludźmi (Miłosz 1985: 185$)^{9}$.

Uwaga ta jest pogłosem poważnych problemów z ogniskową, ponieważ w obiektywie żagarysty perspektywa była zwykle globowa i kosmiczna właśnie dlatego, że ziemia i wszystko co materialne i cielesne wywoływało jego awersję.

\section{Montaż oniryczny}

Wyka zauważył, że w Trzech zimach podmiot patrzy przez grubą soczewkę i tworzy serie ,jaskrawych plam”, ,jest to kraina profetycznych i pogardliwych zapowiedzi, dramatycznych i roztopionych w nadmiarze obrazów walk; trwa

9 Zdaniem Barańczaka poezję noblisty charakteryzuje usilna dążność do „widzenia okiem ptaka i zarazem mrówki [...]. Pewien klucz do zrozumienia tej filmowo-synekdochicznej techniki dał Miłosz w swoim przemówieniu sztokholmskim, odwołując się do pamiętanej w dzieciństwie postaci Nilsa Holgerssona, bohatera Cudownej podróży Selmy Lagerlöf” (Barańczak 1985: 429). 
w niej jakiś niesamowity sabat oderwanych i groźnych gestów, tragicznych znaków duchowych" (Wyka 1985: 18-19). Dlatego są to wizje lunatyczne, a więc właściwe głębokim snom. Miłosz, już wcześniej odwołując się do języka filmu, wprowadza nas w swej poezji do „ogrodów lunatycznych”. Obrazuje te przestrzenie modelowo. Jego modelem są sny katastroficzne. Tak jak słowa, tak również obrazy są w tej poezji dodawane swobodnie i służą ekspresji eschatologicznych pragnień, ponieważ podmiot mówiący pragnie końca złego świata.

Połączenie techniki synekdochiczno-filmowej i poetyki onirycznej polega na zerwaniu jedności miejsca i czasu oraz połączeniu serii tajemniczych obrazów obecnością persony, która jest wyzwolona spod władzy logicznej motywacji postępowania. W wierszach onirycznych persona jest ego alter autora $i$, jak w filmach onirycznych, jest „na zasadzie intruza, kogoś obcego i nieprzystosowanego - w pewnej rzeczywistości, którą sama na swoje podobieństwo deformuje" (Eberhardt 1974: 23), ale - dodajmy - ta deformacja ujawnia tajniki natury i dziejów. Jej alogiczność wyraża się w języku, który nie jest językiem dialogu, lecz językiem oświadczeń, deklamacji, skandowania pod gołym niebem, sobie a muzom. Poetyka oniryczna zbliży niekiedy poezję Miłosza do surrealizmu. Technika filmowo-synekdochiczna przez pokrewieństwo filmu i snu (Film jest snem według Konrada Eberhardta (zob. Eberhardt 1974)) daje bowiem Miłoszowi łatwość obrazowania onirycznego, czyli „stwarzania ekwiwalentów sennych wizji i stanów” (Okopień-Sławińska 1973: 10), bo „sen jest "filmem wewnętrznym», a więc jakby serią ruchomych obrazów” (Eberhardt 1974: 30), ergo: może być wzorcem filmowego obrazowania.

Podmiot wierszy Lą (wizje), Ptaki, Bramy arsenału, Pieśń, Wcielenie przybywa na ziemię z innego świata. Z łatwością właściwą sennym peregrynacjom, poza prawami grawitacji, przemieszcza się w przestrzeni cmentarzy, jezior, parków. Jego przestrzeń jest dychotomiczna, fizyczna i metafizyczna, kosmiczna i ziemska. W Ptakach spotykamy krainę życia napowietrznego, gdzie „Białe dziewczynki ledwo tykały obłoków" (Miłosz 2001: 64).

Bohaterka Pieśni długo przebywa w wymiarze napowietrznym. Jej trwogi wynikają z poczucia kosmicznego wyobcowania. Jest ona nie tylko fizycznie na pograniczu dwóch światów. Jej wyobraźnia opanowana jest przez równoległą przestrzeń i czas apokatastasis. Wielowymiarowości przestrzeni odpowiada rozmaitość czasu fizyki i metafizyki, wymiaru mikro- i makrokosmicznego, lądu i wody. Jej wędrowanie przez świat przypomina mimowolny pobyt w zakładzie penitencjarnym, nic tu od niej nie zależy. Jest przez naturę niesiona na falach ziemskich konieczności. Bardzo często mówi tak, jakby jej przekaz nie miał adresata: 


\begin{abstract}
Ziemia odpływa od brzegu, na którym stoję, i coraz dalej świecą jej trawy i drzewa.

Pączki kasztanów, światła lekkiej brzozy

już nie zobaczę was.

Z ludźmi umęczonymi oddalacie się,

Ze słońcem kołysanym jak flaga biegniecie w stronę nocy.

(Miłosz 2001: 67)
\end{abstract}

Osoba mówiąca przedstawia rzeczywistość w serii obrazów tak fantastycznych jak z koszmaru sennego. Jesteśmy w świecie uchylonych praw grawitacji, ruchu Ziemi jako planety i Słońca, wokół którego krąży. Sama jest medium kosmicznych fal, które ją przerażają. W sposób właściwy marzeniu sennemu traci władzę nad sobą i poddaje się siłom niezależnym od jej woli.

W Bramach arsenału jest ona całkowicie niema. Przybywa do świata jako obcej krainy i jest obiektem pościgu motywowanego pożądaniem. W przestrzeń napięcia erotycznego wkracza siła kosmiczna i przepala wszystko w zgodzie z postulatem montażu rewolucyjnego sformułowanym przez Miłosza w cytowanym wyżej liście do Iwaszkiewicza: „Blask tnie. Od światła wszystko, co żywe umiera" (Miłosz 2001: 71).

Ekspresja właściwego podmiotowi mówiącemu antyświatowego dualizmu wiele w tej poezji zawdzięcza swobodzie skojarzeń poetyki onirycznej. Światło oczyszczenia przepala świat, ale jest to oczyszczenie wrogie życiu na ziemi i ludzkiej prokreacji:
A jeśli dziecko zrodzi się z tej krwi słowiańskiej,
Patrząc bielmem, łbem ciężkim na stopnie potoczy.
(Miłosz 2001: 71, Bramy arsenału)

W dychotomicznym świecie śnionej apokalipsy samoistnego życia nabierają żywioły ognia, powietrza, wody i ziemi. Technika montażu pozwala nie tylko monumentalizować obrazy, ale również tworzyć ich fantasmagoryczne serie. W Ptakach przyzywany ogień oczyszczenia materialnej ziemi poprzedza przywrócenie bytu do pełni poprzez apokatastasis. Pod ogniem „czworga nieb” odnajduje się świat oczyszczony, zaś materia jest:

Oddana we władanie zimnym krzykom pawi.

Mży śnieg. I drzewo każde, przełamane, krwawi.

(Miłosz 2001: 66) 
Obrazy krwawienia przełamanych drzew, panowania pawi w królestwie Baltazara wychodzą spod pióra poety natchnionego niezwykłością skojarzeń surrealizmu. Tę technikę dopuszczającą swobodę skojarzeń odnajdujemy w Powolnej rzece. Antyświatowość ekspresji ujawnia się w skojarzeniu wiosny z oceanem krwi:

Tak pięknej wiosny jak ta już od dawna

Nie miał podróżny świata. Krwią cykuty

Wód przestrzeń mu się wydała rozległa.

(Miłosz 2001: 94)

Oniryczna skojarzeniowość odsłania w niektórych wierszach pokłady mizantropii, awersji wobec rzeczywistości materialnej i cielesnej. Złowroga aktywność materii nieożywionej wieńczy także dzieło Stworzenia w wierszu Do księdza Ch. Przenośnia „ziemi-ust” służy ekspresji rozpoznania jej gargantuicznego apetytu, maszyny pożerającej.

Żywioł powietrza zapełnia przestrzeń w sposób symptomatyczny dla nastawień antyświatowych, gdyż wiatr rozprasza zdobycze cywilizacyjne ludzkości. Od rozległej perspektywy obejmującej w serii obrazów całą ziemię, można więc powiedzieć: od ujęcia globowego do kameralnego i poszczególnego, jesteśmy prowadzeni skokowo w sposób właściwy filmowemu montażowi:

Wieczorem wiatr. Z ciemności wypłoszeni

Głowy toczyli naprzeciw połyskom

Ognia w kominie. Pies, słuchając cieni,

Myślał, kamienny, z łapami przy pysku.

(Miłosz 2001: 89, Wieczorem wiatr)

W świecie demonicznej materii zauważalna jest tendencja do nadawania personie bytu widmowego. Chętnie nazywa się ona - jak widzieliśmy - „podróżnym świata”, „nietrwałym towarzyszem wiatrów ucichłych” (Wcielenie), cieniem, który jednak ślady stóp pozostawia w popękanym żwirze. Ten brak substancjalności jest również charakterystyczny dla obrazowania fantasmagorycznego inspirowanego poetyką snu.

\section{Przemiany poetyki filmowej}

Wizje świata w Poemacie o czasie zastygłym i w wierszach rozproszonych zdradzają Miłoszowe poczucie awangardowości. Zostawiły pamiątkę zaciągniętego 
długu u formacji, której poeta nie pragnął kontynuować. Granice swobody ekspresji treści podświadomych osiągnął w Trzech zimach. Te wiersze przypominają o spokrewnieniu jawy i snu. Wczesne tomiki Miłosza są świadectwem tego, że jego poetyka była zagadnieniem tyleż estetycznym, co moralnym. Poeta dobrze rozumiał, że jego nowa optyka wymaga artyzmu, że zrodzi się wraz z przezwyciężeniem skłonności dualistycznych o antyświatowym charakterze. Ta częściowa przemiana mentalna nastąpiła w środku okupacyjnej nocy i znalazła zapis w zbiorze Świat. Poema naiwne (1943). Poemat ten jest uważany za wiekopomne osiągnięcie artystyczne Miłosza i przykład ewolucji jego filmowej poetyki.

\section{| Bibliografia}

\section{LITERATURA PODMIOTU:}

Miłosz Czesław (1985), Mowy miane w Sztokholmie przy wręczaniu Nagrody Nobla, w: Poszukiwania. Wybór publicystyki rozproszonej: 1931-1983, red. Konrad Piwniczki, CDN, Warszawa.

Miłosz Czesław (1990), Zaczynając od moich ulic, Wydawnictwo Dolnośląskie, Wrocław.

Miłosz Czesław (2001), Wiersze wszystkie, t. 1, Znak, Kraków.

Miłosz Czesław (2002), Wiersze wszystkie, t. 2, Znak, Kraków.

Miłosz Czesław (2009), Wiersze wszystkie, t. 5, Znak, Kraków.

Miłosz Czesław, Iwaszkiewicz Jarosław (2011), Portret podwójny. Wykonany z listów, wierszy, zapisków intymnych, wywiadów i publikacji, wybór Barbara Toruńczyk, Fundacja Zeszytów Literackich, Warszawa.

\section{LITERATURA PRZEDMIOTU:}

Balcerzan Edward (1982), Wieloznaczność „awangardy”, w: tenże, Kręgi wtajemniczenia: czytelnik, badacz, tłumacz, pisarz, Wydawnictwo Literackie, Kraków, s. 317-330.

Barańczak Stanisław (1985), Język poetycki Czesława Miłosza. w: Poznawanie Miłosza. Studia i szkice o twórczości poety, red. Jerzy Kwiatkowski, Wydawnictwo Literackie, Kraków, s. 419-445.

Barańczak Stanisław (200o), Miłosz: „Sześć wykładów wierszem”. Preliminaria interpretacyjne, w: Poznawanie Miłosza 2: 1980-1998, cz. 1, red. Aleksander Fiut, Wydawnictwo Literackie, Kraków, s. 246-262.

Barańczak Stanisław (2001), Summa Czesława Miłosza. w: Poznawanie Miłosza 2: 1980-1998, cz. 2, red. Aleksander Fiut, Wydawnictwo Literackie, Kraków, s. $257-269$. 
Bauchrowicz-Kłodzińska Magdalena (2018), Jonasz w brzuchu wieloryba. Czesław Miłosz wobec nowoczesności, Wydawnictwo Naukowe umk, Toruń.

Brodzka Alina (1975), Spór o wartości w kulturze współczesnej w polskiej prozie narracyjnej, w: Literatura polska 1918-1932, t. 1: 1918-1932, red. Alina Brodzka, Helena Zaworska, Stefan Żółkiewski, Wiedza Powszechna, Warszawa, s. 569-570.

Burek Tomasz (2001), Autobiografia jako rozpamiętywanie losu. Nie tylko o „Rodzinnej Europie”, w: Poznawanie Miłosza 2: 1980-1998, cz. 2, red. Aleksander Fiut, Wydawnictwo Literackie, Kraków, s. 7-28.

Eberhardt Konrad (1974), Film jest snem, wAif, Warszawa.

Eisner Lotte H. (2011), Ekran demoniczny, przeł. Konrad Eberhardt, słowo/obraz terytoria, Gdańsk.

Fiut Aleksander (1993), Moment wieczny. Poezja Czesława Miłosza, Wydawnictwo Literackie, Warszawa.

Głowiński Michał (200o), „Przedmieście” Czesława Miłosza. Próba interpretacji, w: Poznawanie Miłosza 2: 1980-1998, cz. 2, red. Aleksander Fiut, Wydawnictwo Literackie, Kraków, s. 197-211.

Hopfinger Maryla (1974), Kultura audiowizualna a rozumienie literatury, „Pamiętnik Literacki”, z. 4, s. 129-146.

Jędrychowski Stefan (1931), Bezpośrednio przed nami (1). Linia wpisana w koło, „Żagary”, nr 4, s. I.

Kaźmierczyk Zbigniew (2011), Dzieło demiurga. Zapis gnostyckiego doświadczenia egzystencji we wczesnej poezji Czesława Miłosza, słowo/obraz terytoria, Gdańsk.

Koschany Rafał (2007), „Filmowość” i „literackość”. Od estetyki do egzystencji, w: Kino wobec sztuk. Związki - inspiracje - przenikanie: ponowoczesność i wielokulturowość, red. Dorota Skotarczak, Jacek Nowakowski, Wyższa Szkoła Nauk Humanistycznych i Dziennikarstwa, Poznań, s. 9-20.

Kracauer Siegfried (2009), Od Caligariego do Hitlera. Z psychologii filmu niemieckiego, przeł. Eugenia Skrzywanowa, Wanda Wertenstein, słowo/obraz terytoria, Gdańsk.

Kwiatkowski Jerzy (1985), Poemat o czasie zastygłym, w: Poznawanie Miłosza.

Studia i szkice o twórczości poety, red. Jerzy Kwiatkowski, Wydawnictwo Literackie, Kraków, s. 42-67.

Nycz Ryszard (2011), Miłosz wśród prądów epoki. Cztery poetyki, w: Poznawanie Miłosza 3: 1999-2010, red. Aleksander Fiut, Wydawnictwo Literackie, Kraków, s. 17-32.

Okopień-Sławińska Aleksandra (1973), Sny i poetyka, „Teksty”, nr 2, s. 7-23. Okopień-Sławińska Aleksandra (200o), „Przedmieście” jako inna „Piosenka o końcu świata”. Przyczynek do opisu, w: Poznawanie Miłosza 2: 1980-1998, cz. 2, red. Aleksander Fiut, Wydawnictwo Literackie, Kraków, s. 212-229. 
Otto Wojciech (2007), Sytuacja gatunków literackich polskiego międzywojnia w świetle sztuki filmowej, w: Kino wobec sztuk. Związki - inspiracje - przenikanie: ponowoczesność i wielokulturowość, red. Dorota Skotarczak, Jacek Nowakowski, Wyższa Szkoła Nauk Humanistycznych i Dziennikarstwa, Poznań, s. 21-39.

Sławiński Janusz (1965), Koncepcja języka poetyckiego awangardy krakowskiej, Zakład Narodowy im. Ossolińskich, Wrocław.

Wat Aleksander (1993), Bezrobotny Lucyfer, w: tenże: Bezrobotny Lucyfer i inne opowieści, wybór i oprac. Włodzimierz Bolecki, Jan Zieliński, Czytelnik, Warszawa.

Wyka Kazimierz (1985), Ogrody lunatyczne i ogrody pasterskie, w: Studia i szkice o twórczości poety, red. Jerzy Kwiatkowski, Wydawnictwo Literackie, Kraków, s. $15-41$.

Zaleski Marek (1984), Przygoda drugiej awangardy, Zakład Narodowy im. Ossolińskich, Wrocław.

Zagórski Jerzy (1932), Radion sam pierze. Prawo do wiersza, „Żagary”, nr 6, s. 3.

\section{| Abstrakt}

\section{ZBIGNIEW KAŹMIERCZYK}

\section{Filmowość języka poetyckiego Czesława Miłosza}

Artykuł rozwija tezę o filmowości wczesnej poezji Czesława Miłosza, przedstawia jej przesłanki na tle nowatorskich prądów epoki, omawia zastosowanie pojęć języka filmu jako adekwatnych wobec synekdochicznej techniki obrazowania noblisty. Prezentuje ją jako algorytm strukturalny świata poetyckiej wielogłosowości. Ukazuje związek etyki, filozofii, teologii z obrazowaniem wiersza. Dowodzi, że rozwój techniki synekdochiczno-filmowej - od figuratywności do płynności w obrębie ujęcia - związany był z równoważeniem gnostyckiej awersji poety wobec rzeczywistości ciała i materii. Równowaga poczucia grozy istnienia i jego afirmacji sprzyjała tworzeniu płynnych serii: partes pro toto powstałych ze spotkania nazwy i rzeczy darzonej respektem, $\mathrm{z}$ akceptacji bytów, które same w sobie są transcendentne. Autor artykułu stwierdza, że poprzez porównanie języka poezji z językiem filmu możliwe stało się ukazanie poetyckości wierszy Miłosza.

Słowa kluczowe: awangarda; synekdocha; ujęcie; montaż; polifonia; kontestacja; afirmacja 


\section{| Abstract}

\section{ZBIGNIEW KAŹMIERCZYK}

\section{The Movielike Nature of Czesław Miłosz's Poetic Language}

The paper develops the thesis on the movielike nature of Czesław Miłosz's early poetry. It includes the premises of the thesis in contrast to innovative currents of the epoch. The paper discusses applying terms from the language of film as adequate when compared to the Nobel Prize winner's synecdochic technique of imaging which is shown as the structural algorithm of the world of poetic multivoiceness. The paper displays the relation between ethics, philosophy and theology with the imaging of a poem. It proves that the advancement of the synecdochic-film technique, from figurativeness to the fluency of a take, is connected with balancing the Gnostic aversion of the poet towards the reality of body and matter. The balance between the feeling of terror of existence and its affirmation was favourable for creating fluent series: partes pro toto derived from the coming together of a name and a respected item, as well as accepting beings which are transcendent in their nature. The author of the paper states that through comparing the language of poetry and the language of film it was possible to show the poetic nature of Miłosz's poems.

Keywords: avant-garde; synecdoche; take; editing; polyphony; contestation; affirmation

\section{| Nota o autorze}

Zbigniew Kaźmierczyk - dr hab. prof. ug, autor monografii Dzieło demiurga. Zapis gnostyckiego doświadczenia egzystencji we wczesnej poezji Czesława Miłosza (2011), Słowiańska psychomachia Mickiewicza (2012), redaktor naukowy monografii wieloautorskiej Religijność Czesława Miłosza (2020) oraz współredaktor i współautor monografii Adam Mickiewicz i Rosjanie (2020). Napisał ponad sto trzydzieści prac naukowych opublikowanych w Polsce i za granicą - w tym w przekładzie angielskim, rosyjskim, litewskim, ukraińskim. Odsłania gnostycko-manichejski obraz świata i człowieka w literaturze romantyzmu i epok następnych. Zgromadził argumenty na rzecz irańskiej etnogenezy Słowian i ukazuje jej implikacje literaturoznawcze. Literaturę i myśl słowiańską czyta w perspektywie filozoficzno-teologicznej i tworzy kanon dzieł etnogenetycznej historii literatury.

E-mail: zbigniew.kazmierczyk@ug.edu.pl

ORCID: 0000-0002-7716-3911 